\title{
EFFECT OF ENDURANCE EXERCISE ON OXIDATIVE STRESS MARKER MALONDIALDEHYDE IN TYPE 2 DIABETIC MICE.
}

\footnotetext{
1. FCPS (Physiology)

Senior Demonstrator

Akhter Saeed Medical and Dental College.

2. FCPS (Physiology)

Senior Demonstrator

Akhter Saeed Medical and Dental College.

3. M.Phil

Assistant Professor

Fatima Jinnah Medical University.

4. M.Phil, FCPS

Professor

Akhter Saeed Medical and Dental College.
}

Correspondence Address:

Dr. Sana Akram

Senior Demonstrator

Akhter Saeed Medical and Dental

College.

sana.akram1986@gmail.com

Article received on:

$14 / 01 / 2020$

Accepted for publication:

$28 / 04 / 2020$

\begin{abstract}
Sana Akram¹, Maimona Tabssum², Maryam Rao³, Hamid Javaid Qureshi
\end{abstract}
\begin{abstract}
Diabetes is associated with oxidative stress and has a significant role in the pathophysiology of the disease and its complications. Exercise training is a powerful therapeutic approach in diabetes and has protective effects against the progress of its complications. Objectives: The aim of this study was to investigate the effect of an endurance exercise program on the oxidative stress marker malondialdehyde (MDA) in high fat diet-low dose streptozotocin induced type 2 diabetic mouse model. Study Design: Randomized Control trial. Setting: Department of Physiology, Akhtar Saeed Medical and Dental College, Lahore. Period: August 2017 to August 2018. Material \& Methods: 60 male albino mice were fed a high fat diet containing $60 \% \mathrm{kCal}$ as fat for 4 weeks. This was followed by intra peritoneal injection of $40 \mathrm{mg} / \mathrm{kg}$ body weight streptozotocin, given on three consecutive days. Mice with fasting blood glucose more than $250 \mathrm{mg} / \mathrm{dl}$ after a week were considered diabetic. Half the mice underwent an exercise program which comprised of a 20 minute swimming session per day, with a $6 \%$ body weight load attached to the tail of mice, 3 days a week, for 4 weeks. The level of MDA was estimated in both groups using TBARs method. Results: Mean malondialdehyde level was significantly $(p<0.05)$ reduced in diabetic mice that underwent endurance exercise training. Conclusion: This study highlights the important role of endurance exercise in reducing oxidative stress in diabetes.
\end{abstract}

Key words: Diabetes, Endurance Exercise, Oxidative Stress.

Article Citation: Akram S, Tabssum M, Rao M, Qureshi HJ. Effect of endurance exercise on oxidativestress markermalondialdehyde intype2 diabetic mice. Professional Med J 2020; 27(7):1493-1498. DOI: 10.29309/TPMJ/2020.27.07.4486

\section{INTRODUCTION}

Diabetes is related with high oxidative strain, that has an significant role in its etiology and progression. ${ }^{1}$ High insulin levels disturb insulin signaling through NADPH oxidase 4 , a potent enzyme that generates reactive oxygen species. Through a successive chain of events, high levels of ROS cause the Golgi apparatus to translocate GLUT4 for degradation to lysosomes instead of the plasma membrane. ${ }^{2}$ In response to reactive oxygen species, stress pathways like p38 MAPK, NF-kB are activated. This results in increased levels of cytokines causing inflammation like TNFa and IL-6. ${ }^{3}$

Evidence suggests that free radicals also play an important part in the molecular mechanisms of vascular disease in diabetes. ${ }^{4}$ The endothelium fails to secrete adequate quantity of $\mathrm{NO}$ and vessels respond poorly to endothelium- dependent vasodilators. ${ }^{5}$ Hyperglycemia leads to overproduction of the superoxide free radical by mitochondria; and this ROS reacts with NO to produce peroxynitrite. ${ }^{6}$ It also directly inactivates two critical enzymes which protect against atherosclerosis, epithelial NO synthase (eNOS) and prostacyclin synthase. Mitochondrial overproduction of superoxide free radicals activates multiple stress pathways and suppresses the angiogenic response of endothelial cells to ischemia. $^{7}$

Malondialdehyde (MDA) is an in vivo marker of oxidative stress, that is produced by the peroxidation of polyunsaturated fatty acids (PUFA) ${ }^{8}$ It is an organic, highly reactive compound that causes lethal stress in cells and produces covalent protein adducts called advanced lipoxidation end-products (ALE), similar to advanced glycation end-products (AGE). ${ }^{9}$ 
MDA itself promotes atherosclerosis. It reacts with lysine residues and causes cross-linking in apoB portions of OxLDL. Oxidized LDL is taken up by macrophages and leads to foam cell development in atherosclerosis. ${ }^{10}$

Studies have shown that MDA levels are raised in patients of diabetes and are positively related to hyperglycemia and albuminuria, thus proposing that lipid peroxidation plays a pivotal role in the pathophysiology of diabetic complications. ${ }^{11}$

Exercise is a planned and structured form of physical activity. Endurance exercise is a form of physical activity that raises heart rate and stimulates greater use of $\mathrm{O}_{2}{ }^{12}$ Brisk walking, bicycle riding, jogging, and swimming are typical examples. Aerobic/endurance exercises involve recruitment of a substantially large muscle mass. The beneficial effects of exercise in diabetes include improved blood glucose control, lipid profile, arterial pressure and sequel of cardiovascular events. In type 2 diabetics, moderate exercise increases muscle use of blood glucose more than gluconeogenesis in the liver, leading to a decrease in blood levels. Exercise triggers non-insulin dependent GLUT4 translocation, partly through the activation of 5 AMP activated protein kinase. ${ }^{13}$ It enhances mitochondrial biogenesis, enzymes taking part in oxidation, insulin sensitivity, decreases the risk of cardiovascular problems and helps in weight loss. ${ }^{14}$ Regular exercise also impedes the development of diabetes. ${ }^{15}$

\section{MATERIAL \& METHODS}

This randomized control trial was conducted at the Department of Physiology, Akhtar Saeed Medical and Dental College, Lahore.

Duration of Study was from August 2017 to August 2018

Sixty healthy, male albino mice, of 30-40 grams were randomly selected and purchased from the Veterinary Institute and Research Centre, Lahore.
Inclusion Criteria

- Healthy, male albino mice of 30 to 40 grams.

Exclusion Criteria

- Unhealthy mice.

- Mice physically unfit for swimming.

- Mice that did not develop diabetes.

The animals were maintained at the animal house of Akhtar Saeed Medical College. The mice were kept in standard-sized steel cages in a twelve hour light/dark cycle with lights on from 7 am to $7 \mathrm{pm}$. A controlled environment was created with temperature close to $26^{\circ} \mathrm{C}, 50 \%$ humidity and adequate ventilation. ${ }^{16}$

All animal procedures were reviewed and approved by the Ethical Review Committee of Akhtar Saeed Medical College, Lahore.

Type 2 diabetes mellitus was induced in the entire population of mice by a high fat diet- low dose streptozotocin model ${ }^{17}$ that closely mimics the natural pathophysiology of the disease.

\section{a) High Fat Diet}

Mice were fed a high fat diet containing $60 \% \mathrm{kcal}$ as fat, for 2 weeks. High fat diet was constituted by adding lard to standard chow in the appropriate proportion. ${ }^{17}$

\section{b) Administration of Streptozotocin}

After receiving high fat diet for 2 weeks, the mice were given 3 doses of streptozotocin STZ, each of $40 \mathrm{mg} / \mathrm{kg}$ body weight ${ }^{17}$ on 3 consecutive days by intraperitoneal injection. STZ was prepared fresh each day and administered within 30 minutes of constitution. Mice had access to glucose in saline instead of plain water for 24 hours after administration of STZ to prevent fatal hypoglycemia. Fasting glucose levels were measured 1 week after receiving the first dose of streptozotocin. ${ }^{16}$ Blood was drawn from the tail vein and glucose was estimated using a hand held glucometer (AccuCheck). Mice with fasting blood glucose $>250 \mathrm{mg} / \mathrm{dl}$ were labeled diabetic.

Streptozotocin is selectively taken up by pancreatic $\beta$ cells through GLUT2. It causes 
degeneration and destruction of DNA by reacting with cytosine groups. It causes selective $B$ cell destruction and reduces pancreatic reserve. ${ }^{16}$ Combined with a high fat diet that induces insulin resistance, partial $B$ cell destruction by low dose STZ results is hyperglycemia and hyperinsulinemia. This model therefore closely mimics the natural pathophysiology of type 2 diabetes.

The exercise program comprised of a 20 minute swimming session per day, with a $6 \%$ load attached to the tail of mice, 3 times a week on alternate days, for 4 weeks. ${ }^{18}$ Mice were familiarized with swimming for a few minutes daily a week prior to initiation of the exercise study, to allow them to acclimatize to handling of the task.

A circular swimming tank was used, with a width of $65 \mathrm{~cm}$ and length of $50 \mathrm{~cm}$. Water depth was kept at $35 \mathrm{~cm}^{19}$ and $15 \mathrm{~cm}$ was left from above the water level to prevent mice from jumping out.

- Swimming sessions were supervised to prevent any animal from drowning or adopting irregular swimming behavior that could reduce work capacity (like floating) or produce hypoxia (diving).

- The number of mice was restricted to four per session, to prevent any hindrance to swimming and affecting workload.

The temperature of the water was kept between 32 and $36-^{20}$ by warming it with a coiled metallic heating rod and checking the temperature using an alcohol thermometer. This precaution was taken to ensure optimum swimming speed and performance.

MDA concentration was estimated by TBARS method. MDA reacts with thiobarbituric acid to form a colored complex [MDA - (TBA)2 complex] which is measured by spectrophotometery. ${ }^{21}$

$4 \mathrm{mM}$ of TBA reagent was prepared by dissolving
$57.66 \mathrm{mg}$ of TBA in $100 \mathrm{~mL}$ of $20 \%$ glacial acetic acid.

Preparation of Standard MDA Solutions

$1 \mathrm{mM}$ stock solution was prepared by dissolving $31.35 \mathrm{mg}$ of MDA in $100 \mathrm{~mL}$ of $20 \%$ glacial acetic acid. From the stock solution serial dilutions were done to yield multiple concentrations of the standard, in the range of 0.1 to $1.0 \mathrm{mM}$.

$1.5 \mathrm{ml}$ of $0.5 \%$ thiobarbituric acid was mixed with $200 \mu$ of the sample or standard, followed by $200 \mu \mathrm{l}$ of $8.1 \%$ SDS and $1.5 \mathrm{ml}$ of $20 \%$ acetic acid. Distilled water was added to the reaction mixture to a final volume of $5 \mathrm{ml}$ and placed at $90^{\circ} \mathrm{C}$ in a hot water bath for 60 minutes. The mixture was left to cool at room temperature and then $1 \mathrm{ml}$ of distilled water and $5 \mathrm{ml}$ of $\mathrm{n}$-butanol were added. The mixture was then mixed well and placed in a centrifuge machine at $4000 \mathrm{rpm}$ for 10 minutes. The absorbance of the supernatant was measured at $532 \mathrm{~nm}$ against blank using distilled water. The concentration of MDA was determined as:

Serum $\quad \operatorname{MDA}(\mu \mathrm{mol} / \mathrm{L})=$ Absorbance of Sample/Absorbance of Standard $\times$ Standard Concentration $\times$ Dilution Factor

$(\mu \mathrm{mol} / \mathrm{L})$ absorb of standard-absorb of blank conc.

Was carried out using database software and statistical program PASW18 (formerly SPSS) to determine mean, standard deviation and 95\% confidence interval. Student's t-test was applied to compare the levels of parameters and to determine the significance of difference between the groups. $p$ value $\leq 0.05$ was considered significant.

\section{RESULTS}

The diabetic mice that underwent an endurance exercise program for four weeks had significantly $(p=0.000) \quad$ lower serum malondialdehyde (17.07 $\pm 0.56 \mu \mathrm{mol} / \mathrm{L})$ as compared to the diabetic

\begin{tabular}{|l|c|c|c|}
\hline \multicolumn{1}{|c|}{ Serum Parameter } & Diabetic Control $(\mathbf{n = 3 0 )}$ & Diabetic exercise $(\mathbf{n}=\mathbf{3 0})$ & P-Value \\
\hline Malondialdehyde $(\mu \mathrm{mol} / \mathrm{L})$ & $19.94 \pm 1.31$ & $17.07 \pm 0.56$ & $0.000 *$ \\
\hline $\begin{array}{c}\text { Table-I. Comparison of serum glucose, insulin and malondialdehyde between diabetic control and diabetic exercise } \\
\text { groups by student t-test. Values are presented as mean } \pm \text { SD - * }{ }^{*} \text { significance }(p<0.05) \text { at } 95 \% \text { confidence interval }\end{array}$ \\
\hline
\end{tabular}


control mice $(19.94 \pm 1.31 \mu \mathrm{mol} / \mathrm{L})$.

\section{DISCUSSION}

The current study has revealed significant reduction in the oxidative stress marker malondialdehyde in diabetic mice that underwent an endurance exercise regime. Diabetes displays a high level of oxidative stress due to prolonged high levels of glucose which exhaust antioxidant mechanisms and stimulate generation of endogenous free radicals. Oxidative strain has lately been shown to be partly accountable for the $\beta$-cell damage caused by chronic hyperglycemia. Glucose excess causes the formation of several reducing sugars from glycolysis and the polyol pathway; and in this course oxidative free radicals are formed that lead to tissue injury. ${ }^{8}$ We have investigated the effectiveness of endurance exercise training as a therapeutic strategy in reducing oxidative stress in diabetes.

In a study conducted by Kanter et al (2017), the effects of low intensity exercise on the heart of streptozotocin induced diabetic rats was investigated. Treatment of diabetic animals with low intensity exercise reduced tissue MDA levels and improved the activity of the antioxidants superoxide dismutase (SOD), glutathione peroxidase (GSH-Px), and catalase (CAT) in cardiac tissue. ${ }^{22}$

Similarly, in another study, the effect of physical training on oxidative strain in cardiac tissue and blood of STZ induced diabetic rats was investigated. After 6 weeks of voluntary wheel running, there were significantly lower MDA levels in both the cardiac tissue $(p<0.01)$ and blood $(p<0.05) .23$

In a recent study (2019) endurance training of mothers with metabolic syndrome showed a significant reduction in neonatal oxidative stress markers. ${ }^{24}$

Regular physical exercise has shown to be effective in the prevention and delay of type 2 diabetes. ${ }^{25}$ An exercise program consisting of eight weeks of treadmill training improved endurance capacity and positively reduced oxidative stress as measured by TBARS. ${ }^{26}$

\section{CONCLUSION}

Our study showed that endurance exercise reduced diabetes induced oxidative stress.

Copyright $(28$ Apr, 2020.

\section{REFERENCES}

1. Giacco F. Oxidative stress and diabetic complications. Circ Res. 2011; 107:1058-70.

2. Tangvarasittichai S. Oxidative stress, insulin resistance, dyslipidemia and type 2 diabetes mellitus. World J Diabetes. 2015; 6:456-80.

3. Guilherme A, Virbasius J V, Vishwajeet P, Czech MP. Adipocyte dysfunctions linking obesity to insulin resistance and type 2 diabetes. Nat Rev Mol Cell Biol. 2008; 9:367-77.

4. Matough FA, Budin SB, Hamid ZA, Alwahaibi N, Mohamed J. The role of oxidative stress and antioxidants in diabetic complications. Sultan Qaboos Univ Med J. 2012; 12:556-69.

5. Ceriello A, Esposito K, Piconi L, Ihnat MA, Thorpe JE, Testa $R$, et al. Oscillating glucose is more deleterious to endothelial function and oxidative stress than mean glucose in normal and type 2 diabetic patients. Diabetes. 2008; 57:1349-54.

6. Pitocco D, Tesauro M, Alessandro R, Ghirlanda G, Cardillo C. Oxidative stress in diabetes: Implications for vascular and other complications. Int $\mathrm{J} \mathrm{Mol} \mathrm{Sci.}$ 2013; 14:21525-50.

7. Wu M, Yiang G, Lai T, Li C. The oxidative stress and mitochondrial dysfunction during the pathogenesis of diabetic retinopathy. Oxid Med Cell Longev. 2018; 2018:1-12.

8. Ho E, Karimi Galougahi K, Liu CC, Bhindi R, Figtree GA. Biological markers of oxidative stress: Applications to cardiovascular research and practice. Redox Biol. 2013; 1:483-91.

9. Natarajan, K., Mathialagan, G., Raghavan, S. Shanmugam N. The advanced lipoxidation end product precursor malondialdehyde induces IL-17E expression and skews lymphocytes to the Th17 subset. Cell Mol Biol Lett. 2015; 20: 647-62.

10. Wu M, Yiang G, Lai T, Li C. The oxidative stress and mitochondrial dysfunction during the pathogenesis of diabetic retinopathy. Oxid Med Cell Longev. 2018; 2018:1-12. 
11. Kaefer M, De Carvalho JA, Piva SJ, da Silva DB, Becker AM, Sangoi MB, Almeida TC, Hermes CL, Coelho AC, Tonello R, Moreira AP, Garcia SC, Moretto MB MR. Plasma malondialdehyde levels and risk factors for the development of chronic complications in type 2 diabetic patients on insulin therapy. Clin Lab. 2012; 58:973-8.

12. Nojima H, Yoneda M, Watanabe H, Yamane K, Kitahara Y, Sekikawa K, et al. Association between aerobic capacity and the improvement in glycemic control after the exercise training in type 2 diabetes. Diabetol Metab Syndr. 2017; 9:1-10.

13. Richter EA, Hargreaves M. Exercise, GLUT4, and Skeletal Muscle Glucose Uptake. Physiol Rev. 2013; 93:993-1017.

14. Inzucchi SE, Bergenstal RM, Buse JB, Diamant $M$, Ferrannini $E$, Nauck $M$, et al. Management of Hyperglycemia in Type 2 Diabetes, 2015: A PatientCentered Approach: Update to a position statement of the american diabetes association and the european association for the study of diabetes. Diabetes Care. 2015; 38:140-9.

15. Standards of medical care in diabetes-2015 abridged for primary care providers. Clin Diabetes. 2015; 33:97-111.

16. Furman BL. Streptozotocin-Induced Diabetic Models in Mice and Rats Streptozotocin-Induced Diabetic Models. Curr Protoc Pharmacol. 2015; 70:1-20

17. Gilbert ER, Fu Z, Liu D. Development of a nongenetic mouse model of type 2 diabetes. Exp Diabetes Res. 2011; 2011:416254.

18. Cunha VN, de Paula Lima M, Motta-Santos D, Pesquero $\mathrm{JL}$, de Andrade RV de AJ et al. Role of exercise intensity on GLUT4 content, aerobic fitness and fasting plasma glucose in type 2 diabetic mice. Cell Biochem Funct. 2015; 33:435-42.

19. Napoli C, Williams-Ignarro S, De Nigris F, Lerman LO, Rossi L, Guarino C et al. Long-term combined beneficial effects of physical training and metabolic treatment on atherosclerosis in hypercholesterolemic mice. Proc Natl Acad Sci USA. 2004; 101:8797-880.
20. Mizunoya W, Oyaizu S, Ishihara K, Fushiki T. Protocol for Measuring the Endurance Capacity of Mice in an Adjustable-current Swimming Pool. Biosci Biotechnol Biochem. 2002; 66:1133-6.

21. Adewole SO, Ojewole JAO. Protective effects of Annona muricata Linn. (Annonaceae) leaf aqueous extract on serum lipid profiles and oxidative stress in hepatocytes of streptozotocin-treated diabetic rats. African J Tradit Complement Altern Med. 2009; 6:30-41.

22. Kanter M, Aksu F, Takir M, Kostek O, Kanter B, Oymagil A. Effects of Low Intensity Exercise Against Apoptosis and Oxidative Stress in Streptozotocin-induced Diabetic Rat Heart. Exp Clin Endocrinol Diabetes. 2017; 125:583-91.

23. Naderi R, Mohaddes G, Mohammadi M, Ghaznavi R, Ghyasi R, Vatankhah AM. Voluntary Exercise Protects Heart from Oxidative Stress in Diabetic Rats. Adv Pharm Bull. 2015; 5:231-6.

24. Azizi azar sharabyani G R, Ahmadi M, Shadmehri S. The effect of endurance training in maternal metabolic syndrome with metformin on oxidant and antioxidant capacity in their neonates. ljdld. 2019; 8:135-146.

25. Derouich M, Boutayeb $A$. The effect of physical exercise on the dynamics of glucose and insulin. $J$ Biomech 2002; 35: 911-917.

26. Gul M, Laaksonen DE, Atalay M. et al. Effects of endurance training on tissue glutathione homeostasis and lipid peroxidation in streptozotocin-induced diabetic rats. Scand. J. Med. Sci. Sports. 2002; 12: 163-170.

27. Farhangi N, Nazem F, Zehsaz F. Effect of Endurance Exercise on Antioxidant Enzyme Activities and Lipid Peroxidation in the Heart of the StreptozotocinInduced Diabetic Rats. JSSU. 2017; 24:798-809. 


\begin{tabular}{|c|c|c|c|}
\hline \multicolumn{3}{|c}{ AUTHORSHIP AND CONTRIBUTION DECLARATION } \\
\hline Sr. \# & Author(s) Full Name & \multicolumn{1}{|c|}{ Contribution to the paper } & Author(s) Signature \\
\hline 1 & Sana Akram & $\begin{array}{l}\text { Experimental work and data } \\
\text { collection, Drafting and } \\
\text { critically revising the work for } \\
\text { important intellectual content. } \\
\text { Proof reading. }\end{array}$ \\
\hline 3 & Maimona Tabssum & $\begin{array}{l}\text { Mata analysis and } \\
\text { interpretaiton. } \\
\text { Contribution to concept and } \\
\text { study design. }\end{array}$ \\
\hline 4 & Hamid Javaid Qureshi & \\
\hline
\end{tabular}

